\title{
Sphagnum Moss as Growing Medium in Phalaenopsis Orchid
}

\author{
M.M. Kaveriamma ${ }^{*}$, P.K. Rajeevan ${ }^{2}$, D. Girija ${ }^{2}$ and K. Nandini ${ }^{2}$ \\ ${ }^{1}$ DST Young Scientist University of Agricultural and Horticultural Sciences College of \\ Forestry, Kodagu, India \\ ${ }^{2}$ Kerala Agricultural University College of Horticulture, Kerala, India \\ *Corresponding author
}

\section{Keywords \\ Phalaenopsis Orchid, Klebsiella pneumoniae, Wilt, Moss \\ Article Info \\ Accepted: \\ 15 January 2019 \\ Available Online: \\ 10 February 2019}

\begin{abstract}
A B S T R A C T
Phalaenopsis orchids occupy a top position in the international market as pot plant. Commonly used media for growing Phalaenopsis orchid are coconut husk chips, tree bark, fir bark, cocopeat and sphagnum moss. Growing medium is important as it provides anchorage, retains moisture, nutrients and aerates the roots. In addition to these functions, a study was carried out to assess the possible growth promoting effects of sphagnum moss on orchids when used as growing medium. Eight month old hardened plants of Phalaenopsis 'Magic Kiss' were used for the trial. They were planted in translucent plastic pots with three different growing media viz., coarse coconut husk chips, cocopeat (fine coconut husk bits) and sphagnum moss in combination with charcoal and tile bits. Plants grown in sphagnum moss were significantly superior to those grown in coconut husk chips and coconut husk bits as media, both in terms of vegetative and floral attributes. Root cross section of sphagnum moss grown plants revealed healthy velamen and their root parenchyma tissues were rich in chlorophyll. From the moss surface, bacterial isolates of Bacillus thuringensis and B. aryabhattai were identified. Endophytic nitrogen fixing bacteria Klebsiella pneumoniae was isolated from leaves and roots grown in moss. Plants grown in moss had no incidence of wilt caused by Fusarium oxysporum. The isolates tested positive for IAA production.
\end{abstract}

\section{Introduction}

Phalaenopsis, commonly called the moth orchids is the most important commercial genus of orchids. Phalaenopsis are short stemmed monopodial orchids. Plants are slow growing and mature plants attain an average height of twelve to fifteen centimeters, although a few individuals may grow taller (Sahavacharin, 1981).
Growing medium is important as it provides anchorage, retains moisture, nutrients and aerates the roots. In addition to these functions, a study was carried out to assess the possible growth promoting effects of sphagnum moss on orchids when used as growing medium. In the Western Ghats of India, epiphytic orchids are found growing in abundance on trees covered with sphagnum moss. Sphagnum leaves are highly 
specialised; they form a special tissue of living, chlorophyll-containing chlorocytes and dead cell content-free hyalocytes, which are responsible for their huge potential to store water. Galacturonic acid is rich in carboxylic acid groups that give Sphagnum its high cation exchange capacity (Spearing, 1972). Acidity generally retards microbial metabolism. Sphagnum species also produce bioactive secondary metabolites influencing microbial colonisation. Living Sphagnum mosses are colonised in high abundances with specific microorganisms, which fulfil important functions like nutrient supply and pathogen defence for moss growth and health (Opelt et al., 2007). Tens of thousands of microbial species associate with plants, and plant-microbe interactions are crucial to plant health (Lundberg et al., 2012). Microbes have the potential to benefit plants through nutrient acquisition, disease suppression, and modulation of host immunity (Mendes et al., 2011).

\section{Materials and Methods}

The present study was carried out at the top ventilated rain-shelter greenhouse of the All India Co-ordinated Floriculture Improvement Project at the Department of Pomology and Floriculture, College of Horticulture, Vellanikkara. The site is situated at a latitude of $10^{\circ} 31^{\prime} \mathrm{N}$ and longitude of $76^{\circ} 13^{\prime} \mathrm{E}$. The area lies $22.25 \mathrm{~m}$ above MSL. The experimental site enjoyed a humid tropical climate with maximum and minimum average temperatures of $36.59^{\circ} \mathrm{C}$ and $21.30^{\circ} \mathrm{C}$ during the period of investigation. The mean relative humidity varied from 46.86 per cent to 78.70 per cent. The light intensities varied between 6000 and 11000 Lux. Eighteen months old plants of Phalaenopsis 'Magic Kiss' were used to assess the influence of three different types of growing media, namely coconut husk chips, cocopeat and sphagnum moss. Fifteen plants were included under each treatment.
The plants were grown in the respective media along with charcoal and tile bits. Transluscent plastic pots were used as container. Sphagnum moss growing as parasites on coffee plants in Kodagu district nestled in Western Ghats were used. Coconut husk was collected locally, chipped into 2 inches blocks, soaked in water for 48 hours to remove tannins and later used. Commercial grade cocopeat blocks were used after soaking for 48 hours and draining out excess moisture. Microbial load was analyzed in media, in phyllosphere and rhizosphere for plants grown in sphagnum moss and without moss. It was done using serial dilution technique. Bacterial identification was done using 16S rDNA sequencing at the Department of Microbiology, Kerala Agricultural University.

\section{Results and Discussion}

Orchids exhibit a wide range of habitats, terrestrial and epiphytic plants occupying the major share of plant genera. In the epiphytic orchids, a variety of media are used, the main functions of such media being, providing good aeration, holding moisture and allowing good drainage. Media like tree bark, coconut husk, charcoal, brick pieces, tile bits etc are popular with epiphytic orchids. The media is also reported to be genus specific. Wang (2005) reported that, while growing phalaenopsis in containers filled with artificial medium, important considerations are aeration, capillary action, water and nutrientholding capacities, stability and weight of the medium components, as well as cost and consistency. In the present study, three different growing media were used namely coconut chips, cocopeat and sphagnum moss. Coconut husk chips and cocopeat are commonly used for growing orchids. There have been reports on sphagnum moss being a good media for orchids in terms of good moisture holding capacity but not in terms of 
nutrient supply and microbial load. Although moss from New Zealand is of higher quality, many growers use Chilean moss because it is less expensive. For the trial, high quality long threaded moss growing on trees and shrubs especially from coffee plantations (where it is considered a parasite) from Kodagu in the Western Ghats were used. They were superior and very well suited for phalaenopsis growing. Vegetative and floral characters were studied and also plant tissue and media were analysed for nutrients, chlorophyll content and bacterial colonies (Table 1 and 2).

\section{Vegetative characters}

Good vegetative growth is an indication of the photosynthetic ability of plants. Among the treatment plants, plants grown using sphagnum moss as media was found to have a significantly better vegetative growth. Plants were significantly taller, with an increase of $1.64 \mathrm{~cm}$ when sphagnum moss was used as medium. Plants grown in cocopeat and coconut husk chips were on par with an increase of $0.21 \mathrm{~cm}$ and $0.40 \mathrm{~cm}$ respectively. Significant differences were observed with regard to leaf characters among treatments. Leaf length, leaf breadth and leaf area were maximum with $16.72 \mathrm{~cm}, 9.87 \mathrm{~cm}$ and 87.78 $\mathrm{cm}^{2}$, respectively, in plants where sphagnum moss was used. It was minimum in plants grown with cocopeat, recording $8.94 \mathrm{~cm}, 5.32$ $\mathrm{cm}$ and $42.00 \mathrm{~cm}^{2}$ which were on par with plants grown in coconut husk chips as growing medium. Remarkable differences were noted with regard to the interval of production of leaves in plants where sphagnum moss was used as the growing medium, compared to the other two (Table 1). New leaves were produced at an interval of 91.40 days in treatment with sphagnum moss, which was significantly superior to coconut chips (221.90 days) and cocopeat (260.50 days). This is in agreement with the studies of Wang (2005) who reported that pure sphagnum moss could probably be the single best material for growing young phalaenopsis in warm (tropical and subtropical) conditions.

\section{Flowering and floral characters}

A strong base of vegetative characters resulted in better flowering characters of plants grown in moss, compared to those using coconut chip bits and coconut husk bits. Inflorescence emergence occurred at the earliest (124.90 days) in the treatment plants where moss was used as the medium. Time taken for emergence of inflorescences was on par when coconut husk chips and cocopeat were used with values 153.30 days and 155.90 days, respectively. Significant differences were observed among treatments in the number of inflorescences produced. Inflorescence count of 1.80 per year was recorded in plants grown in moss. This was significantly superior compared to coconut chips bits and cocopeat which recorded 0.90 and 0.80 , respectively and were on par. The inflorescence produced was significantly longer. Significant differences were observed with regard to flowering duration among treatments. It was maximum (112.70 days) in plants where moss was used and the values were on par when coconut husk chips and cocopeat were used (73.40 and 70.10 days, respectively). Inflorescence length recorded highest value $(28.17 \mathrm{~cm})$ in plants where moss was used as media. It was significantly superior to coconut husk chips and cocopeat as media wherein the length of inflorescence was $14.80 \mathrm{~cm}$ and $14.03 \mathrm{~cm}$, respectively. Number of flowers per inflorescence was the maximum (7.30) in sphagnum moss as medium. The values were significantly superior to coconut husk chips and cocopeat (3.30 and 2.10, respectively) which were on par. Difference in flower size among treatments was not significant though flower size was better in moss grown plants. 
Table.1

\begin{tabular}{|l|l|l|l|l|l|l|l|}
\hline Growing medium & Plant & \multicolumn{3}{|l|}{ Leaf Character } & \multicolumn{3}{l|}{ Inflorescence Character } \\
\hline & Height & Length & $\begin{array}{l}\text { leaf } \\
\text { area } \\
(\mathrm{cm})\end{array}$ & $\begin{array}{l}\text { Interval of } \\
\text { leaf } \\
\text { production } \\
\text { (Days) }\end{array}$ & $\begin{array}{l}\text { Days for } \\
\text { emergence }\end{array}$ & $\begin{array}{l}\text { Infloresce- } \\
\text { nce length } \\
(\mathrm{cm})\end{array}$ & $\begin{array}{l}\text { Flower } \\
\text { count } \\
\text { (number) }\end{array}$ \\
\hline Sphagnum moss & $1.64^{\mathrm{a}}$ & $16.72 \mathrm{a}$ & $87.78 \mathrm{a}$ & $91.40^{\mathrm{a}}$ & $124.90^{\mathrm{a}}$ & $28.17^{\mathrm{a}}$ & $7.30^{\mathrm{a}}$ \\
\hline Coconut husk chips & $0.40^{\mathrm{b}}$ & $9.87 \mathrm{~b}$ & $39.30^{\mathrm{b}}$ & $221.90^{\mathrm{b}}$ & $153.30^{\mathrm{b}}$ & $14.80^{\mathrm{b}}$ & $3.30^{\mathrm{b}}$ \\
\hline Cocopeat & $0.21^{\mathrm{b}}$ & $8.94 \mathrm{~b}$ & $42.00^{\mathrm{b}}$ & $260.50^{\mathrm{b}}$ & $155.90^{\mathrm{b}}$ & $14.03^{\mathrm{b}}$ & $2.10^{\mathrm{b}}$ \\
\hline
\end{tabular}

Table.2 Details of bacteria in Sphagnum moss and Phalaenopsis orchid grown without moss

\begin{tabular}{|c|c|c|c|c|c|}
\hline NO. & $\begin{array}{l}\text { Name of } \\
\text { isolate }\end{array}$ & Source & Colony morphology & Cell shape & $\begin{array}{l}\text { IAA production } \\
(\mu \mathrm{g} / \mathrm{ml})\end{array}$ \\
\hline 1. & M1-MM1 & Moss -surface & $\begin{array}{l}\text { Circular, entire, } \\
\text { smooth, glistening }\end{array}$ & $\begin{array}{l}\text { G+ve } \\
\text { rods }\end{array}$ & 44 \\
\hline 2. & MD1 & Moss -surface & $\begin{array}{l}\text { Rough } \\
\text { undulate }\end{array}$ & $\begin{array}{l}\text { G+ve } \\
\text { chain }\end{array}$ & 40 \\
\hline 3. & MY & $\begin{array}{l}\text { Orchid in presence of } \\
\text { moss-Surface of leaf \& } \\
\text { root ; endophytic in leaf }\end{array}$ & $\begin{array}{l}\text { Yellow fluidal } \\
\text { Convex, } \\
\text { Entire, } \\
\text { circular }\end{array}$ & $\begin{array}{l}\text { G-ve } \\
\text { rods }\end{array}$ & 72 \\
\hline 4. & MW & $\begin{array}{l}\text { Orchid leaf surface } \\
\text { (grown with moss) }\end{array}$ & $\begin{array}{l}\text { Circular Entire, } \\
\text { Smooth, glistening }\end{array}$ & $\begin{array}{l}\mathrm{G}+\mathrm{ve} \\
\text { rods }\end{array}$ & 30 \\
\hline 5. & LWMY & $\begin{array}{l}\text { Orchid leaf surface } \\
\text { (grown in coconut husk) }\end{array}$ & Yellow circular & G-ve & 47 \\
\hline 6. & LWMW & $\begin{array}{l}\text { Orchid leaf surface } \\
\text { (grown in coconut husk) }\end{array}$ & $\begin{array}{l}\text { White Circular, } \\
\text { transparent }\end{array}$ & G-ve & 64 \\
\hline 7. & $\begin{array}{l}\text { Moss-red } \\
\text { (imprinting) }\end{array}$ & Moss- surface & Red, Undulate & G+ve & NA \\
\hline 8 & $\begin{array}{c}\text { Moss- } \\
\text { (imprinting) }\end{array}$ & Surface of moss & white undulate & G+ve & NA \\
\hline
\end{tabular}


The endogenous growth regulators could possibly be responsible for the high growth rate in these plants. Hiller et al., (1979) reported that the changes in endogenous gibberellin like activity were related with stem elongation, but not with floral initiation. Flower count was significantly superior in plants grown in moss. Stoessl and Arditti (1984) reported that orchids are known to produce various phenolic compounds and phytoalexins, which were shown to suppress a number of different microorganisms. Plant exudates also supply the rhizosphere with tryptophan that is the main precursor in microbial IAA biosynthesis (Kravchenko et al., 2004). IAA producing bacteria transform it into auxin, increasing its exogenous level. Nitrogen-fixing bacteria belonging to PGPB (Plant Growth Promoting Bacteria) can fix atmospheric nitrogen and supply it to plants. Here we use the term PGPB as bacteria including diazotrophic bacteria or plant growth-promoting rhizobacteria (PGPR). PGPB can competitively colonize plant root, promote plant growth, and reduce plant diseases. In order to further understand the superiority shown by sphagnum moss, the population and types of microflora (surface as well as endophytic) associated with the three substrates were assessed. A Gram negative rod shaped bacterium that formed highly fluidal yellow colonies on nutrient agar was found to be the most predominant in moss. This isolate fixes nitrogen, solubilizes insoluble $\mathrm{P}$ and produces $\mathrm{HCN}$. It also produces IAA from tryptophan, to the extent of $72 \mu \mathrm{g} \mathrm{ml}^{-1}$ of the medium, in a period of two weeks, in pure culture. This isolate was identified as Klebsiella pneumoniae by $16 \mathrm{~S}$ rDNA sequencing. The isolate was associated with phalaenopsis, both in leaves and roots as endophytes and also on the surface of leaves, when the orchids were grown on moss. Population was more in leaf $\left(203 \times 10^{3} \mathrm{cfu} / \mathrm{g}\right)$ than in roots $\left(11 \times 10^{3} \mathrm{cfu}\right)$. The bacterium could not be detected when the plants were grown in the other two media. In vitro studies with cowpea seeds indicated enhancement of germination percentage and seedling vigour. Sachdev et al., (2009) report that six IAA producing strains of Klebsiella significantly increased root length and shoot height of inoculated wheat seedlings over control. Bacillus thuringensis and B. aryabhatti were recorded as well in plants grown in moss as media. The plants grown using sphagnum moss had no incidence of disease. Plants grown in coconut based media recorded higher incidence of collar rot caused by Fusarium oxysporum. Besides the provision of nurients, plant-associated bacteria are important for supporting growth, health and stress resistance of plants.

\section{Acknowledgement}

Authors are grateful to All India Co-ordinated Research Project in Floriculture for the financial assistance received for the research project.

\section{References}

Hiller, L., Kelly, W.C. and Powell, L.E. 1979. Temperature interactions with growth regulators and endogenous gibberellin-like activity during seed stalk elongation in carrots. Plant Physiol. 63: 1055-1061.

Kravchenko, L.V., Azarova, T.S., Makarova, N.M. and Tikhonovich, I.A. 2004. The effect of tryptophan present in plant root exudates on the phytostimulating activity of rhizobacteria. Microbiol. 73: 156-158.

Lindow, S.E., and Brandle, M.T., 2003. Microbiology of the phyllosphere. $1 \mathrm{Appl}$ Environ Microbio. 2003 Apr; 69(4):1875-83.

Lundberg DS, Lebeis SL, Paredes SH, Yourstone S, Gehring J, Malfatti S, Tremblay J, Engelbrektson A, Kunin V, 
del Rio TG et al., 2012. Defining the core Arabidopsis thaliana root microbiome. Nature 488: 86-90.

Mendes, R., Kruijt, M., De Bruijn, I., Dekkers, E., Van der Voort, M., Schneider, J. H. M., Piceno, Y. M., DeSantis, T. Z., Andersen, G. L., Bakker, P. A. H. M., and Raaijmakers, J. M. 2011. Deciphering the rhizosphere microbiome for disease-suppressive bacteria. Science 332:1097-1100.

Opelt, 2007 Investigations of the structure and function of bacterial communities associated with Sphagnum mosses. Environ Microbiol. 2007 Nov; 9(11): 2795-809.

Sachdev, D.P., Chaudhari, H.G., Kasture, V.M., Dhavale, D.D. and Chopade, BA.2009. Isolation and characterization of indole acetic acid (IAA) producing Klebsiella pneumoniae strains from rhizosphere of wheat (Triticum aestivum) and their effect on plant growth. Ind. J Exp Biol. 47(12): 9931000.

Sahavachrin, O.1981. Induction of plantlets on inflorescence of Phalaenopsis by application of N-6-benzyl adenine. Kasetsart Journal of Natural science 15(2):54-64

Spearing, A.M., 1972. Cation-Exchange Capacity and Galacturonic Acid Content of Several Species of Sphagnum in Sandy Ridge Bog, Central New York State. The Bryologist 75(2): 154-158

Stoessl, A. and Arditti, J. 1984. Orchid phytoalexins. In: Arditti J (ed) Orchid biology: reviews and perspectives. Cornell university press, Ithaca, NY. 151-175.

Wang, Y.T. 2005. Phalaenopsis mineral nutrition. ISHS Acta Horticulturae 878: 7

\section{How to cite this article:}

Kaveriamma, M.M., P.K. Rajeevan, D. Girija and Nandini, K. 2019. Sphagnum Moss as Growing Medium in Phalaenopsis Orchid. Int.J.Curr.Microbiol.App.Sci. 8(02): 2118-2123. doi: https://doi.org/10.20546/ijcmas.2019.802.245 